山田一裕

岩手県立大学総合政策学部

\title{
A Study of Water Pollution and Purification on Environmental Education
}

\author{
Kazuhiro YAMADA
}

Faculty of Policy Studies, Iwate Prefectural University

（受理日2010年1月 8日）

\section{Iはじめに}

公共用水域の水質污濁に係わる環境基準には、 有害な化学物質から人の健康を保護するための環 境基準（健康項目）と、生活環境の保全に関する 環境基準（生活環境項目）がある。法律の整備な どにより、1970年代以降、健康項目の環境基準 達成は速やかに進んだ。一方、生活環境項目（有 機污濁指標である BOD CODなど）の基準達成 状況は芳しくない。この原因として、水域への污 濁負荷源として大きな割合を占める生活系由来の 排水が挙げられる。このため、下水道や浄化槽な どの排水処理施設の整備が進められ、普及率は 2006年度で $82.4 \%$ （環境省 2008）に達している。

さらに、水質污濁防止法を改正（1990年）し、 生活排水対策の総合的推進に関しての規定を設 け、家庭内で調理くずなどの分別や廃食用油など の処理、洗剤の適正使用など、個人の責務を明確 にした。また、河川法の改正（1997年）では、 従来の「治水」「利水」に加えて「環境保全」や 「地域住民の意見の反映」の観点が盛り込まれた。 小学校などでは「生活と水」を題材に学習が行な われたり、地域の水辺保全のために、具体的な環 境浄化に取り組んでいるところも少なくない。そ のため、水質污濁の防止に向けた意識啓発や環境 教育はもちろんのこと、環境技術・科学の正しい 理解もますます重要である。

そこで本稿では、「水の污れ」と「污水の浄化」
に関わる実験教材・プログラムの現状と課題を整 理するとともに、科学・技術的な考察を加える。

\section{II＼cjkstart水が污れるとは}

\section{1.「污れ」の発生と水質指標}

一般に、水の污れには、有害化学物質污染、有 機污濁、富栄養化、病原性微生物污染などがある。

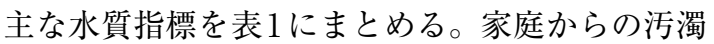
では、にごりや有機物（油や米のとぎ汁など）、 栄養塩類、洗片などが中心である。また、生活を 営む地域からの污濁には、事業所（工場や飲食店 など）排水などがあるが、とくに、農地や山林な ど污濁発生源を特定できない所（面源負荷源）か らも多くの栄養塩類が排出されている。これは、 湖沼や内湾など水が淀みやすい閉鎖性水域の富栄 養化を招き、環境基準の達成を阻んでいる。

なお、電気伝導度や濁度、酸化還元電位など専

表 1 主な水質指標の分類

\begin{tabular}{|c|c|}
\hline 分 & 水質指標 \\
\hline 一般的な指標 & $\begin{array}{l}\text { 外観、色、臭気、 } \mathrm{pH} \text { 、電気伝導度 }(\mathrm{EC}) \\
\text { 透視度、懸濁物質 }(\mathrm{SS}) \text { 、濁度 }\end{array}$ \\
\hline 有害化学物質指標 & 重金属、農薬、有機塩素化合物 \\
\hline 有機污濁指標 & $\begin{array}{l}\text { 有機物質 (BOD、COD、TOC) } \\
\text { 溶存酸素 }(\mathrm{DO}) \text { 、水生生物 } \\
\text { 酸化還元電位 }(\mathrm{ORP}) 、 \text { 硫化水素 }\left(\mathrm{H}_{2} \mathrm{~S}\right) \\
\end{array}$ \\
\hline 富栄養化指標 & $\begin{array}{l}\text { 栄養塩類（窒素 N、リン P） } \\
\text { クロロフィル a (chl-a) }\end{array}$ \\
\hline 衛生学的な指標 & 一般細菌数、大腸菌群数 \\
\hline
\end{tabular}

問い合わせ先 ₹ 982-8577 仙台市太白区八木山香澄町 35-1 東北工業大学環境情報工学科 山田一裕 
門の測定器具を必要としたり、農薬や有機塩素化 合物、クロロフィル a、大腸菌群数など煩雑な分 析をしなければならない項目以外は、比較的扱い やすい簡易測定・分析試薬が市販され、児童でも 実測が可能である。環境調査活動でも簡易測定手 法・道具は広く利用されている。

\section{2. 生活からの污れに関わる教材・プログラム}

水問題に関しては、小学校では社会科や家庭科 において、生活に欠かせない水、家庭での水の污 れ、家庭からの污水による河川などへの影響につ いて学ぶ機会がある。社会科 $3 \cdot 4$ 年「住みよい くらしをつくる」（日本標準教育研究所 2004a） の「水はどこから」では暮らしの中で使われる水 が水源地からどのようにやってくるのかを探り、 浄水場のしくみや、発展として使用後の水（污水） をきれいにする下水処理場の働きについて学ぶ。 5 年生では、「わたしたちの国土と環境」の「わ たしたちの生活と環境」で、京都の鴨川や琵琶湖 の環境を守る取り組みや生活排水の影響について 学ぶ。さらに、中学校技術・家庭科では、生活に 必要な知識と技術の習得によって家庭生活や社会 生活と技術との関わりについて理解を深めさせ、 生活の充実向上を図る能力と実践的な態度の育成 をねらいとしている。とくに環境教育にかかわる 領域に「木材加工」や「電気」などの他、「家庭 生活」・「食物」がある。「食物」領域で扱う「日 常食の調理」では、食器を洗った排水や食べ物の 残りによる污水が河川の水質污濁の主な原因であ ることを理解させ、それを防ぐための具体的な調
理・処理方法を学ばせている（文部省 1991）。

表2に、水の污れのしくみに関する実験教材 · プログラムを紹介する。家庭からの有機污濁に関 する、真山（1993）や山本（2003）の模擬実験で は、水質変化も簡易水質分析試薬などで確認でき るので、身近な素材から生じる污れが意外にも大 きなものであることに気づく。一方、中村ら （2005）や山田（2006）は、家庭からの污水が排 出先の水域でどのように変化し、更なる污濁を招 くのか、を観察する実験教材を提案している。実 験中の水質変化については、栄養成分の変化のほ か、培養によって増殖した植物プランクトンをに ごりとして計測（透視度計や目測など）できる。 これらの実験学習については、小学校 5 年生以上 であれば、「物の溶け方」や「植物の発芽と成長 条件」「植物のからだの働きと日光との関係」な ど（日本標準教育研究所 2004b）を学んでいる ので、作業する上で大きな制約はないと考える。

\section{III 污れた水をきれいにする}

\section{1.「污れ」の大きさ (溶けている/溶けていない) を考える}

一般的に水質分析上、孔径 $0.5 \sim 1 \mu \mathrm{m}$ (1000 分の $1 \mathrm{~mm}$ ）のろ紙で試料をろ過した時、万紙上 の残留物はにごりの成分（懸濁物質）として、ろ 液中に残った成分は溶けている成分（溶存物質） として扱う。懸濁物質であるか、溶存物質である かは、水の浄化方法を考える重要な要素である。 污れの大きさとそれに対応した主な浄化方法を 図 1 に示す。ほぼ特定の成分しか含まれていない

表2 水の污れのしくみに関する実験教材・プログラム

\begin{tabular}{|c|c|c|c|}
\hline テーマ名 & $\begin{array}{ll}\text { 内 } & \text { 容 } \\
\end{array}$ & 対 & 文 \\
\hline $\begin{array}{l}\text { 生ゴミからくる水質 } \\
\text { 污染の教材化 }\end{array}$ & $\begin{array}{l}\text { 生ゴミを通して出てきた污水の水質を測定する。ゴ } \\
\text { ミ（の発生状況）と污れとの関係や家庭からの発生 } \\
\text { 抑制についてを考えさせる。 }\end{array}$ & $\begin{array}{l}\text { 中学生 } \\
\text { (理科) }\end{array}$ & $\begin{array}{r}\text { 真山 } \\
(1993)\end{array}$ \\
\hline $\begin{array}{l}\text { COD ってなに ? } \\
\text {-水質污染の測定- }\end{array}$ & $\begin{array}{l}\text { 家庭で水を污す原因になりそうな食べ物・飲み物・ } \\
\text { 洗剤を試薬で反応させ, 有機物の問題、三角コーナー } \\
\text { (固形物排除) の役割などを理解する。 }\end{array}$ & $\begin{array}{l}\text { 高校生 (理科) } \\
\text { 一般 (イベント)* } \\
* \text { : 筆者判断 }\end{array}$ & $\begin{array}{r}\text { 山本 } \\
(2003)\end{array}$ \\
\hline $\begin{array}{l}\text { 豆腐を用いた水質污 } \\
\text { 濁と富栄養化現象の } \\
\text { 理解 } \\
\end{array}$ & $\begin{array}{l}\text { コップに入れた水と豆腐だけを使って、短期間での } \\
\text { 水質污濁（有機物）現象と長期間（2ケ月）静置によ } \\
\text { る藻類発生を観察する。 }\end{array}$ & $\begin{array}{l}\text { 小・中学生等 } \\
\text { (総合学習*) } \\
* \text { : 筆者判断 }\end{array}$ & $\begin{array}{l}\text { 中村ら } \\
(2005)\end{array}$ \\
\hline $\begin{array}{l}\text { 植物プランクトン培 } \\
\text { 養による富栄養化現 } \\
\text { 象の学習 }\end{array}$ & $\begin{array}{l}\text { 含有成分比の異なる栽培用市販栄養剤を用いて植物 } \\
\text { プランクトンを培養 (約1週間) し、富栄養化におよ } \\
\text { ぼす栄養成分の影響を学ぶ。 }\end{array}$ & $\begin{array}{l}\text { 小学校高学年 } \\
\text { ( 理 科 ) 〜 } \\
\text { 一般 (イベント) }\end{array}$ & $\begin{array}{r}\text { 山田 } \\
\text { (2006) }\end{array}$ \\
\hline
\end{tabular}




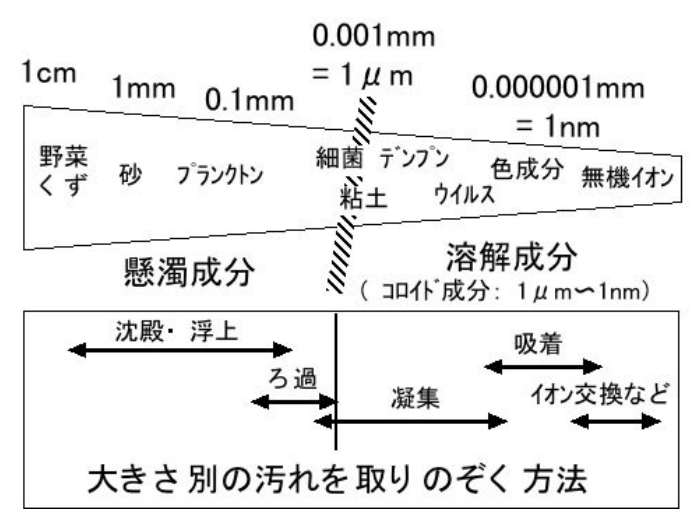

図 1 污れの大きさで考える浄化方法 丹保・小笠原 (1985) を参考に作成

工場排水と違って、生活排水や河川水には多種多 様の污れが含まれている。そのため、これらを取 り除くには、いくつかの方法を組み合わせなけれ ばならない。浄水場では、「(凝集) 沈殿」-「ろ 過」一「消毒」の操作、下水処理場では、「沈殿」 -「生物処理 (分解)」-「沈殿」-「消毒」の 操作を主に施す。これらの用語は、小学校 4 年生 社会科で触れることができる。また、河川中では、 沈殿や分解などが総合的に作用することで污濁成 分が徐々に取り除かれる。これを「自浄作用」と 呼び、川の働きを学ぶ重要な視点である。水域の 健全性を保つには、自浄作用には限界があること を知り、自浄作用を麻盘させない生活のあり方 （污水の制御）が求められる。

物理化学的な污水処理を模擬実験で紹介する教 材・プログラムがある。ペットボトルを使って、 砂を詰めたろ過（成美堂出版編集部 2003）や炭・ 活性炭を使った吸着（馬場 1997：早川 2002）な どは、児童が浄化装置を手作りできることもあり、 よく知られている。しかし、ろ過操作にとって重 要なのは、対象になるにごりの大きさと砂（ろ材） の釣り合いとろ過時間の掛け方である。ちなみ に、現在では少なくなった緩速ろ過処理を施す浄 水場でのろ過速度は 3〜 $5 \mathrm{~m} /$ 日であり、砂の厚 みが $20 \mathrm{~cm}$ であれば 1 時間かけてろ過することを 示す。現在主流の急速ろ過処理では凝集剤によっ てにごりを大きく変化させてからろ過しているの
で、ろ過時間は緩速ろ過の 20 分の 1 程度、 $2 \sim 3$ 分で間に合う。すなわち、学習においても、ろ過 に必要とする時間はにごりの大きさで大きく異な ることを理解しておく必要がある。また、炭や活 性炭を使った吸着・ろ過実験でも、対象の着色成 分にもよるが、実験水を装置内にしばらく留めて おくなど、吸着時間を確保しておく必要がある。

\section{2. 微生物による浄化を考える}

表3に、微生物による浄化について紹介した実 験教材・プログラムを紹介する。

まず、浄化対象となる污水には、実排水・河川 水と人工污水が挙げられている。多くは、河川水 や水道水に污濁物質であるデンプンや米とぎ汁な どを加えたものである。実験資材の調達には人工 污水の作成が便利である。大仲（1996）や田村 （1996）が紹介するデンプンは、植物が生産する 有機物として、児童・生徒にも馴染みがある。ま た、生活排水に見立て、米のとぎ汁や石けん水を 主体にして排出源を考慮した人工污水もある（山 田 2008)。

つぎに、浄化方法として、污水を微生物が存在 する実河川水に混入させる方法（佐藤ら 1993）、 微生物が付着したレキ（河川の底石）に污水を接 触させる方法 (小倉 1987、大仲 1996、冨田 ら 2001)、活性污泥法など污水に高濃度の好気性 微生物を混入させる方法 (田村 1996、小 堀 2004、山田 2008）がある。後者ほど高污濁水 を対象に実験ができる。人工污水の濃度は、川石 などを使う場合には CODが $50 \mathrm{mg} / 1$ 以下、活性污 泥を利用できるなら 100 200mg/1程度とし、ばっ 気をしながら数日〜 1 週間程度の水質变化を観察 するのが適当である。

水中の有機物分解には「微生物と溶存酸素」の 存在が重要であることを学ぶことができる。田村 （1996）は、川の石による埩化作用を $0.2 \%$ デンプ ン溶液と通気の有無で観察（高校生対象）させ、 石表面の微生物と水の中に十分な酸素があること で分解が進むことを伝えている。

一方, 光合成細菌や乳酸菌, 酵母などの微生物 群からなる市販の微生物製剤を使った、小学生を 
表3 微生物による水の浄化に関する実験教材・プログラム

\begin{tabular}{|c|c|c|c|}
\hline テーマ名 & $\begin{array}{ll}\text { 内 } & \text { 容 } \\
\end{array}$ & 対 & 文 献 \\
\hline $\begin{array}{l}\text { 付着整備生物の役割を調 } \\
\text { ベる }\end{array}$ & $\begin{array}{l}\text { 河川水または下水の上澄みを対照に、水のみと水と微 } \\
\text { 生物の付いた石を組み合わせた験によって浄化に果 } \\
\text { たす付着微生物の役割を調べる。ばっ気あり。 }\end{array}$ & $\begin{array}{l}\text { 一般* } \\
*: \text { 筆者判断 }\end{array}$ & $\begin{array}{l}\text { 小倉 } \\
(1987)\end{array}$ \\
\hline 微生物による環境浄化 & $\begin{array}{l}\text { 実河川水や湧水に模擬雑排水を加え、COD 值の変化を } \\
\text { 見て微生物の役割を理解する。ばっ気なし。 }\end{array}$ & $\begin{array}{l}\text { 中学生 } \\
\text { (理科) }\end{array}$ & $\begin{array}{l}\text { 佐藤ら } \\
(1993)\end{array}$ \\
\hline 微生物による水の浄化 & $\begin{array}{l}\text { 川水にデンプンのりを加え、付着微生物のついた小石 } \\
\text { の有無で COD の変化を観察する。ばっ気あり。活性污 } \\
\text { 泥に異なる量のデンプンのりを加え、比較する。 }\end{array}$ & $\begin{array}{l}\text { 中学生 } \\
\text { (理科) }\end{array}$ & $\begin{array}{c}\text { 大仲 } \\
(1996)\end{array}$ \\
\hline $\begin{array}{l}\text { 水をきれいにしてくれる } \\
\text { 微生物たち }\end{array}$ & $\begin{array}{l}\text { デンプン水または希釈牛乳を用いて活性污泥の浄化能 } \\
\text { 力をばっ気や污泥の有無で探る。川の石による浄化作 } \\
\text { 用もばっ気の有無で観察し、微生物と酸素の必要性を } \\
\text { 理解する。 }\end{array}$ & $\begin{array}{l}\text { 高校生 } \\
\text { (理科) }\end{array}$ & $\begin{array}{c}\text { 田村 } \\
\text { (1996) }\end{array}$ \\
\hline 河川の自浄作用 & $\begin{array}{l}\text { 異なる川の石をそれぞれ水路に並べ模擬河川を作成 } \\
\text { し、洗剤と D-グルコースを循環接触させて浄化作用を } \\
\text { 調べる。 }\end{array}$ & $\begin{array}{l}\text { 小・中学生 } \\
\text { (総合学習) }\end{array}$ & $\begin{array}{l}\text { 冨田ら } \\
(2001)\end{array}$ \\
\hline $\begin{array}{l}\text { 池の污泥を用いた水の浄 } \\
\text { 化実験 }\end{array}$ & $\begin{array}{l}\text { 池底の浮泥を牛乳を薄めた人工污水に加え水質変化を } \\
\text { 観察する。ばっ気あり。 }\end{array}$ & $\begin{array}{l}\text { 中学生 } \\
\text { (理科) }\end{array}$ & $\begin{array}{l}\text { 小堀ら } \\
(2004)\end{array}$ \\
\hline 微生物による污水の浄化 & $\begin{array}{l}\text { 米とぎ汁を主体にした人工污水を用いて、微生物（活 } \\
\text { 性污泥）の有無、ばっ気の有無の組み合わせを最低4系 } \\
\text { 作成し、水質変化を観察する。 }\end{array}$ & $\begin{array}{l}\text { 小中学生 } \\
\text { (理科) }\end{array}$ & $\begin{array}{r}\text { 山田 } \\
(2008)\end{array}$ \\
\hline
\end{tabular}

対象にした教材・プログラムがある。丸山 (1998) は、「水と人間の関わり」から、人が污した水を 川の中で浄化してくれる微生物の存在に気づかせ た上で、市販の微生物製剤による浄化の実験・観 察をさせている。微生物製剂の原液の中に 1 日つ けておいた小石をデンプン水 $(2 \mathrm{~g} / \mathrm{l})$ の中に入れ、 2 日後にヨウ素デンプン反応で浄化の具合を測る ものである。ただし、一般的な好気性微生物によ る水質浄化ではなく、嫌気性微生物などを使った 学習は、生物学的分解である腐敗 (タンパク質・ アミノ酸の分解) と発酵（糖類の分解）の区別に ついて、小学生は学ぶ機会がない。

ところで、学習教材で扱われる機会が見られな い、どぶ川の泥の中で硫化水素などの悪臭（腐敗） を放しながら活動している嫌気性微生物も、時間 をかけてへドロ（有機物）を分解し浄化に貢献し ている。嫌気性微生物による污泥発生量（増殖し た微生物量）は、好気性微生物のそれのおよそ5 分の 1 であり、副次的な廃棄物を軽減化しながら エネルギー源としてのメタンガスを回収できる利 点がある（李 2004）。

好気性微生物を主に利用している下水処理場で は、污水中に溶存している有機物は微生物によっ て分解され、半分は二酸化炭素に、残りは微生物
（下水污泥と呼ぶ）の体になって固定化される。 生活排水は当初から固形物（懸濁物）も多いので、 除去される BOD当たり 7〜9割もの污泥が発生す る（須藤 2004）。そのため、毎日膨大な污泥が処 理場から発生し、日本全体で年間約 8 千万トン (2005年度)、全産業廃棄物発生量の 2 割近くを占 める（環境省 2008）。これは、一般廃裹物発生量 の5.3千万トンよりも多い。実際的には、約 7割(乾 燥重量ベース）が有効利用されているものの、排 水処理には污泥発生に伴う廃棄物処理とそのため のエネルギー消費、污水の生物分解に伴う二酸化 炭素発生など、さまざまな副次的な課題があるこ とも理解したい。

\section{3. 環境学習を通じての浄化活動を考える}

地方では、生活排水処理施設の整備率が全国平 均よりも低いので、河川の污濁が局所的に存在し ている。遅々として進まない施設整備に代わっ て、地域住民による污濁削減活動や水域の清掃活 動が広く行われている。このような活動は学術的 に評価されて報告される機会は少ないが、環境学 習の一環として、川や池などの浄化活動を新聞報 道で知る機会が多い。そこで、会員制有料データ 検索サービスを提供する G-Search データベース 
サービス ${ }^{1)}$ を使って、全国紙 4社、地方紙 25 社に 過去 10年間（1999～2008年）に掲載された記事 をキーワード検索して、川の浄化活動の取り組み を探ってみた。キーワードには、河川などで実践 されている主な浄化方法である、「植物」「微生 物」「炭」、そして、比較のため河川整備の方法 として「清掃」、「事」を取りあげた。

その結果、[「浄化」+「環境学習」+「川」]（以 下、キーワード群の A とする) で494件あった。 そのうち、浄化方法として考えられるキーワード を追加したところ、「A」+「植物」が112件、「A」 $+\lceil$ 微生物」が91件、「A」+「炭」が90件、「A」 $+\lceil$ 清掃」が85件、「「A」+「工事」が 68 件であっ た。ただし、各キーワードで重複する記事もある。 つぎに、検索で抽出された実践地の他、浄化方法 にかかわる各キーワードに関する学術的な評価例 を述べる。

「植物」について、検索できた新聞見出しがす べて植物による水質浄化を示しているわけではな い。実践例としては、水生植物であるヨシやマコ モ、水耕栽培としてクレソンやセリを植栽して、 水を流して浄化を図るものがある（広島県芦田川 など)。また、ビオトープを作り、環境学習の拠 点として活用する例もある（石川県水と緑のふれ あいパークなど)。一般的には、湿地や湖沼流入 河川や湖岸部を利用しているものが多い。

生活雑排水が流入する河川に設けられたヨシ植 栽水路 $\left(828 \mathrm{~m}^{2} 、 90 \mathrm{~m}\right.$ の流路）で検討した田畑ら （1996）の研究では、年間を通してBODの除去率

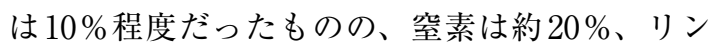
は約 $30 \%$ であった。霞ヶ浦の湖岸帯にヨシを植 栽した人工湿地 $\left(343 \mathrm{~m}^{2} 、 31 \mathrm{~m}\right.$ の流路）に污濁河 川水を流入させて浄化した森田（2002）の研究に よれば、滞留 1 時間以上であればBODの除去率 は30\%程度以上が見込める。ただし、生育した 植物の刚り取りや水位上昇時に流路をふさぐ障害 物とならないかなど、メンテナンス上の課題もあ るので、地域住民の協力や学習を通じての意識啓 発が重要である。

「炭」を用いて川を浄化する体験活動（日本児 童教育振興財団 1995）や地域活動は全国（三重
県勢田川、大分県大野川、岐阜県比衣川など）で 実施されている。ネットやカゴに炭を詰め、川底 などに敷き詰めて、有機物浄化や脱臭を図る方法 である。東京都南浅川で住民が中心になって実施 した河川浄化では、 $120 \mathrm{~kg}$ の木炭をネットに小分 けし、8mにわたり川底に投入した（加藤 1988）。 その結果、臭気やアンモニアの改善がみられた が、ネットの周囲に污泥が張り付き、炭の中に水 が流れなくなった。

炭による有機物の吸着能力も重要だが、炭は微 生物との親和性（付着性）が良いので、炭の広い 表面（細孔）が利用され、有機物の分解が進むと 考えられる。そのため、有機污濁性の高い河川水 では、炭の表面が微生物の固まり（污泥）で覆わ れ、表面積の減少、水の流れの悪化 (流路の閉塞) により、除去性能を維持できなくなる。桜木・篠 原（1994）の実験（福岡県熊添川、木炭 $2000 \mathrm{~kg}$ を $15 \mathrm{~m}$ にわたり敷き詰める）でも、BODの平均

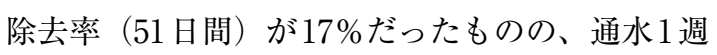
間後に浄化施設内の流速が4分の1に急減してい る。このような污泥や堆積物による閉塞を改善す るため、酒井ら（1995）は、装置内でばっ気洗浄 操作等を加え、下水 2 次処理水の浄化実験を試み た。装置内での滞留時間が 30 40分でもBODは 70 ～80\%の除去がされた。また、炭の表面積を 増やすため、木材ではなくダンボールで炭を作 り、人工排水で水質浄化を検証した高校生の取り 組み（青木 2006）もある。炭も微生物を保持す る担体である以上、付着微生物が活性を維持する ための適度な増殖と剥離がなくてはならない。清 掃などのメンテナンスも考慮し、浄化能力が継続 的に発揮できるかどうかの検証が必要である。

「微生物」については、市販の微生物製剤やそ れをもとに培養した液や団子状にしたものを河川 などに直接投入し、微生物相を变化させて水質浄 化を図る方法が検索された。一般的に、新設の下 水処理場や浄化槽を立ち上げるとき、処理機能を 速やかに安定化させるため、浄化が安定している 既設の污泥（微生物）が種として投入される。ま た、油や難分解性のベンゼンやフェノールなどを 特異的に分解する菌を污染現場に投入し、活用す 
るものも知られている（渡辺 2006）。污染が起き てから、その污染物質を分解する微生物が効果的 に浄化するまで増えるには長い時間がかかる。人 為的な微生物の投入は、この時間を短縮し、浄化 促進が期待できる。しかし、污染現場の環境条件 や生態学的な不適合により、単離（または集積） された微生物を導入することの有用性は限定的で ある。すなわち、河川は物や水が常に流動する開 放系の場である。例え培養器で育てた微生物で あっても、川に投じた時点で淘汰され、その場の 環境条件に見合った微生物相に遷移していく。そ のため、開放的な水域に微生物を投入した場合の 効果の判断は難しい。

例えば、微生物製剂を構成する光合成細菌つい ては、それを利用した排水処理が 30 年以上も前 に実用レベルに至っている（小林・黒沢 1977）。 空気のない嫌気条件下、光を利用して、有機物の 腐敗で生じる有機酸や硫化水素を栄養として利用 する光合成硫黄細菌は臭気改善に役立つ。また、 好気条件下であれば、有機物を利用して污水浄化 に働く光合成非硫黄細菌もいる。近年でも、固定 化した光合成細菌を使い、養鯉水槽水の浄化（永 富ら 2001）が検討されている。いずれも、処理 装置内などの閉鎖的な環境（環境条件を制御でき る場所）で使用されている。

市販の微生物製剤を野外で使った水質浄化につ いて、各地の事例を全国の自治体にアンケート調 査した香川県高松市のまとめ（2004年 3 月時点、 照会件数 273 件中、回答 221 件 $)^{2)}$ では、取り組み による効果について「取り組みの効果を把握して いない」回答のほか、「悪臭とへドロの減少」な ど感覚的な効果を挙げる例が多い。また、不忍池 (東京都上野) で微生物製剂を使った実証試験 (星 野 2002) では、アオコの制御、透視度とともに 浄化目標に至らなかった。

\section{$\mathrm{N}$ 考 察}

現況の水域では、主に有機污濁問題と栄養塩類 などによる水域の富栄養化問題があり、それらの 原因物質は生活と大きな関わりがあることを述べ た。污濁物質の浄化には個々の物質の大きさや性
状に応じた手法が用いられている。しかしなが ら、各浄化方法の特徵や適用条件を考慮しない学 習プログラムや浄化活動が散見された。

一般的に、河川水や下水の浄化において微生物 は重要な働きをする。小学校 4 年生で下水処理場 を知る機会もあり、環境保全に果たす微生物の機 能を理解することは可能である。その場合、微生 物が機能する条件として、酸素、栄養 (有機物)、 微生物量、温度、水質（pHなど）があり、まず はこれらの諸条件と浄化効果について理解させる 必要があろう。また、児童に対して「観察、比較、 分析」する能力を養うには、酸素の有無、好気性 微生物の有無、水温（夏季と冬季）などを比較し た実験学習が有効であり、簡単に取り組めそうな 学習教材・プログラムの提案もあった。さらに、 微生物の働きに及ぼす環境条件を知ることで、例 えば河川水質の保全には、微生物が活動する空間 としての水辺のあり方、微生物の捕食者との関係 (健全な生態系) も大切な要素であることも学べる。

一方、浄化に一般的な好気性微生物とは別に、 嫌気性微生物も環境中にはごく普通に存在してい る。河川水中でも好気的な部分と嫌気的な部分は 存在し、それらに応じた微生物が污濁物質を分解 して、川は浄化されていく。ときとして、嫌気性 微生物は腐敗臭をもたらし、そのようすが河川水 質悪化の姿として捉えられている。しかしなが ら、有害なトリハロメタンなどの有機塩素化合物 を分解する特殊な細菌もこのような泥の中から発 見されている。嫌気性微生物にも適材適所の役割 があることを認識したい。

浄化活動において、取り組みのキーワードとし て挙げた「植物」や「炭」は、各素材に浄化能力 があるのはもちろん、微生物の住みかとして嫌 気・好気など多様な場を提供させることに価值が ある。上述したように、微生物による浄化は、微 生物の投入だけで済むものではなく、その機能を 高めるための環境作りを伴わなければならない。 例えば、子どもたちに「微生物を投入しておけば 水質が改善される」という短絡した “答え”を提 供しているような授業や活動では、科学的な思考 が省かれており、問題解決のために自らの判断と 
行動ができる人材を養っていくための環境教育と は言えない。

また、水域の浄化に微生物が投入される場合、 微生物培養液そのものが米のとぎ汁等を含み、 BOD 濃度で下水の $21 \sim 59$ 倍（3社 5 検体）もあ る高濃度の有機性廃液である（福島県生活環境部 水環境グループ 2008)。10リットルも流せば、 1 人 1 日あたりの污濁負荷に匹敵する。公共用水域 の管理者側からすれば、有機污濁源となるものを 安易に投入されるのは望まない。ましてや、環境 学習では生活のあり方を見なおして污濁物の削減 を指導しており、培養液とはいえ、高濃度の有機 物を流すことに学習指導者は疑問を感じるべきで あろう。

微生物の生理学的性質を踏まえ、その微生物の 能力が十分発揮できるように環境条件を地域住民 らが整え、その過程を児童らに伝えていくことが 環境教育に成りはしないだろうか。すなわち、生 活由来の污濁を削減し、適当な河川清掃（泥やゴ ミの処理など）をして、河川水の流動性を高めた り、植栽を施して生物の多様性を高める等の工夫 である。

以上をふまえ、水質浄化をテーマにした（実験） 学習や活動・実践における科学的な視点をつぎに 示しておく。

・原因となる污濁物質の性状や環境条件をもと に、浄化方法を選択すること。

・実験条件を明確にした比較をして浄化方法の判 定をすること（実践活動の場合、対象河川が1 つなら、浄化を試みる前に 1 年間程度は何もし ないで観察する等)。

・観察項目 (水質指標) を選び、デー夕収集・分 析を定期的に行なうこと。

- 可能な限り定量的な浄化効果の判断をして、成 否にかかわらずその要因を理解しておくこと。

\section{$\mathrm{V}$ おわりに}

教室で、生活のあり方と水の污れとの関係やそ の対策について学んだ後、それを地域の中で実践 できる場や協力者がいるとするならば、児童・生 徒の学習環境は大変恵まれていると言える。
水質污濁の防止は、水域への污濁排出を削減す ることが基本である。それには、「污濁源を少な くする」、「個々の污濁源からの発生量を減らす (油の拭き取りなど)」、「発生した污濁を処理して から水域に排出する（下水道整備、浄化槽の設 置)」ことである。児童・生徒には学びを通して、 まずは自ら、家族からできる生活の工夫を実践し てもらいたい。地域の生活排水対策が遅れている なら、合併処理浄化槽などの設置を行政や地域社 会に提案してもらいたい。それでもなお身近な水 域の水質改善が図れないなら、その水域の実情を 学び、それに合わせた浄化方法を選択し、地域の 大人を巻き込んで実践をしてもらいたい。

\section{注}

1 ) (株) ジー・サーチ, 新聞・雑誌記事横断検索, http://db.g-search.or.jp/, アクセス : 2009年 2 月 4 日.

2 ）高松市都市整備部下水道管理課, EMを活用 した水質浄化活動の調査結果,

http://www.city.takamatsu.kagawa.jp/3221. html, アクセス : 2009年 2 月 5 日.

\section{引用文献}

青木博久, 2006,「ダンボール炭で水質浄化」, 食 農教育, $46: 52-53$.

馬場勝良, 1997, 『炭と墨の実験』ささ・方·ら書房, 東京, 63 .

福島県生活環境部水環境グループ, 2008, 「微生 物資材の河川等への投入を水環境保全から考え る」, 『生活排水対策推進指導員講習会資料』, 15.

早川信一, 2002, 『身近な実験で学ぶ地球環境』,

丸善, 東京, 164 .

星野豊, 2002,「EM菌を利用した公園池の浄化」,

『緑の読本』, $64: 65-70$.

環境省,2008,『平成 20 年版 環境 循環型社会白

書』, 日経印刷, 東京, 416 .

加藤文江, 1988, 「浅川周辺住民の手づくりの河 川浄化：木炭による浄化の実験から」, 『水質污 濁研究』, $11: 24-26$. 
小林正泰 · 黒沢慶二, 1977, 「光合成細菌（PSB） によるし尿家畜ふん尿の無稀釈浄化処理」、ケ ミカル・エンジニアリング』, $22: 881-888$.

小堀志津子 - 田代知子 - 平野ひとみ, 2004,「池 の污泥を用いた水の浄化実験 : 教材開発」, 『宇 都宮大学教育学部教育実践総合センター紀要』, 27 : 97-110.

丸山典雄, 1998 , 「小学校理科における自然と人 間との関わりに対する見方を育てる授業実践 :

EM (有効微生物群) を使った浄化作用の学習 を通して」, 『日本科学教育学会研究会研究報 告』, $12(7): 35-40$.

真山恵子, 1993, 「生ゴミからくる水質污染の教 材化」, 山極隆編著, 『中学校理科で進める環境 教育』, 明治図書, 東京, 59-65.

文部省，1991，「中学校技術・家庭科における環 境教育の指導」、環境教育指導資料（中学校· 高等学校編), 大蔵省印刷局, 東京, 69-73.

森田弘昭, 2002, 「低湿地浄化法の水質浄化特性 について」,『下水道協会誌』, 39(481): 109-122. 永富寿 - 竹野健次 - 渡辺昌規 - 佐々木健 ・ ハン チュヤン, 2001, 「固定化光合成細菌による養 鯉水槽水の簡易浄化と脱窒」, 『水環境学会誌』, $24: 64-68$.

中村玄正・渡邊豊・佐藤洋一, 2005,「環境教育

における水質污濁および富栄養化現象の理解の ための豆腐利用による水質変化観察簡易実験の 提案」,『水環境学会誌』, $28: 745-750$.

成美堂出版編集部, 2003, 『中学生の環境とリサ イクル自由研究』, 成美堂出版, 東京, 143 .

日本標準教育研究所, 2004a, 『小学校教科書単元 別・到達目標と評価基準 $<$ 社会 $>$ 東 $3 \sim 6$ 年』, 東京, 105.

日本標準教育研究所, 2004b, 『小学校教科書単 元別・到達目標と評価基準 $<$ 理科 $>$ 東3 6年』, 東京, 126.

日本児童教育振興財団, 1995, 『環境教育実践マ ニュアル Vol.1』, 小学館, 東京, 429 .

小倉紀雄, 1987, 『調べる・身近な水』, 講談社, 東京, 166.
大仲政憲, 1996,「微生物による水の浄化」,『理 科の教育』, $45(10): 20-23$.

李玉友, 2004, 「メタンへの最大転換率」, 須藤隆 一編著, 『水環境保全のための生物学』, 産業用 水調查会, 東京, 168-169.

酒井信行 - 南後和憲 - 高村弘人,「河川水の直接 浄化のための上向流木炭接触酸化法」, 『水環境 学会誌』, $18: 663-669$.

桜木建治・篠原啓児, 1994, 「木炭を利用した河 川浄化」, 『福岡県保健環境研究所年報』, 21 : 62-65.

佐藤成哉・青井弘毅 - 井上二夫, 1993, 「環境教 育の資料作成 II : 水質污染と自浄作用」, 『熊 本大学教育学部紀要: 自然科学』, $42: 13-18$. 須藤隆一, 2004, 「污泥発生量」, 須藤隆一編著, 『水 環境保全のための生物学』, 産業用水調查会, 東京, 65-66.

田畑真佐子 - 加藤聡子 - 川村晶 - 鈴木潤三 · 鈴木 静夫, 1996,「ヨシ植栽水路における河川水中 の窒素・リンの除去効果」,『水環境学会誌』, 19 : 331-338.

田村直明, 1996,「水をきれいにしてくれる微生 物たち：STS教育をめざした活性污泥の教材 化」,『生物教育』, $36: 162-173$.

丹保憲仁・小笠原紘一, 1985, 『浄水の技術』, 技 報堂出版, 東京, 390 .

富田敬子・喜多雅一 - 近森憲助 - 村田勝夫, 2001, 「河川の自浄作用に関する研究とその教 材化」, 『化学と教育』, $49: 364-366$.

山田一裕, 2006, 「水の富栄養化問題を学習する ための教材の開発」、『日本環境教育学会第 17 回大会研究発表要旨集』, 59 .

山田一裕, 2008,「生活排水対策にかかわる環境 教育の現状と新たな教材の提案」、用水と廃 水』, $50: 68-74$.

山本喜一, 2003,「CODってなに？：水質污染の

測定」, 東京理科大学サイエンス夢工房編, 『楽

しむ化学実験』, 朝倉書店, 東京, 151-153.

渡辺一哉, 2006, 「有用微生物の導入による生物

処理の高度化」, 『用水と廃水』, $48: 102-107$. 